\title{
Not too slow, not too fast: water currents affect group structure, aggression and welfare in post- smolt Atlantic salmon Salmo salar
}

\author{
Frida Solstorm ${ }^{1,2, *}$, David Solstorm ${ }^{1}$, Frode Oppedal ${ }^{1}$, Rolf Erik Olsen ${ }^{1,3}$, \\ Lars Helge Stien ${ }^{1}$, Anders Fernö ${ }^{1,2}$ \\ ${ }^{1}$ Institute of Marine Research, 5984 Matredal, Norway \\ ${ }^{2}$ Department of Biology, University of Bergen, PO Box 7803, 5006 Bergen, Norway \\ ${ }^{3}$ Department of Biology, Norwegian University of Science and Technology, 7491 Trondheim, Norway
}

\begin{abstract}
Increased swimming speed of Atlantic salmon is generally considered an improvement to welfare under aquaculture settings, as group structure is improved and agonistic behaviour reduced. As such, establishing fish farms in exposed areas with fast water current velocities should be favourable. However, at some locations, velocities exceed what is known as preferable for salmonids, and this may compromise fish welfare. In this study, behaviour and fin erosion were observed on post-smolt salmon stocked at $39 \mathrm{~kg} \mathrm{~m}^{-3}$ in raceways at 3 water current velocities: fast $(1.5$ body lengths $\left.[\mathrm{BL}] \mathrm{s}^{-1}\right)$, moderate $\left(0.8 \mathrm{BL} \mathrm{s}^{-1}\right)$ and slow $\left(0.2 \mathrm{BL} \mathrm{s}^{-1}\right)$. Movements that affect group structure and interactions between individuals varied by up to 20 -fold between velocities. A behavioural change occurred directly after velocities were set. Severe fin erosion decreased over time in all groups, but new injuries increased almost 3-fold in the faster-velocity group. Our results suggest that moderate velocity is ideal from a welfare perspective. At slow velocity, higher frequency of structural movements and between-individual interactions could be stressful for the fish. At faster velocity, the fish have to focus on swimming, which could increase unintentional collisions with obstacles and other individuals and result in new fin erosion. Our results suggest that management of water currents may be an effective way of controlling behaviour and may thereby improve welfare.
\end{abstract}

KEY WORDS: Exposed farming $\cdot$ Swim speed $\cdot$ Environmental variability $\cdot$ Swimming behaviour

\section{INTRODUCTION}

Motivational drivers for swimming in wild Atlantic salmon include migration, feeding, predatory avoidance and mating. For fish in aquaculture systems, few of these drivers are functional. Farmed fish cannot move to another habitat, they do not need to hunt food or avoid predators, and they usually do not mature sexually. In the marine life stages, wild salmonids swim on average at 1 body length (BL) s ${ }^{-1}$ (Drenner et al. 2012). This is similar to observed swimming speeds in salmon farms (Sutterlin et al. 1979, Kadri et al. 1991, Blyth et al. 1993, Juell \& Westerberg 1993). In the

\footnotetext{
*Corresponding author: frida.solstorm@imr.no
}

wild, this cruising speed is suggested to be the energetic optimum with lowest cost of transport (Drenner et al. 2012). Similarly, a laboratory study by Tudorache et al. (2011) showed that the optimal swimming speed for brook charr Salvelinus fontinalis was $1 \mathrm{BL} \mathrm{s}^{-1}$ and that this corresponded to the preferred swimming speed $\left(0.8\right.$ and $\left.1.0 \mathrm{BL} \mathrm{s}^{-1}\right)$ when the fish was free to choose. Swimming at a preferred speed may be considered positive for welfare. One approach to fish welfare is the Five Freedoms (defined by the UK's Farm Animal Welfare Council [FAWC 1995]). One of the freedoms concludes that the animal should be free to express normal behaviour; swimming at a preferred

() The authors 2016. Open Access under Creative Commons by Attribution Licence. Use, distribution and reproduction are unrestricted. Authors and original publication must be credited. 
speed could be considered a normal behaviour and, hence, positive for welfare.

An increasing number of salmon farms are now located in exposed areas with fast water current velocities, where the fish are forced to swim faster than their preferred speed. Previous laboratory studies have, to our knowledge, only demonstrated positive behavioural effects of increased swimming speeds, which would imply improved welfare (e.g. Korte et al. 2007). Slow current velocities may result in more interactions between individuals and increased aggression that could result in fin erosion (Christiansen \& Jobling 1990, Jørgensen \& Jobling 1993, Adams et al. 1995, Turnbull et al. 1998) and promote secondary infection (Schneider \& Nicholson 1980), reducing production performance and welfare (Stien et al. 2013). Faster current velocities have been reported to reduce agonistic behaviour and create a more ordered group structure with higher production performance (East \& Magnan 1987, Christiansen \& Jobling 1990, Jørgensen \& Jobling 1993, Adams et al. 1995). Based on this, fast current velocities in exposed areas could be considered positive for the fish up to an unknown critical level. However, at water velocities above $0.7 \mathrm{BL} \mathrm{s}^{-1}$, Johansson et al. (2014) observed a breakdown of the circular group structure in Atlantic salmon Salmo salar in net cages. When the current increased further to $0.9 \mathrm{BL} \mathrm{s}^{-1}$, all fish abandoned the circular school structure and maintained a position facing the current. As the current shifted, there was a chaotic and challenging transition before a new group structure was established. This indicates that the fish strive for structure to cope with the dynamic environment and the high densities in the cage (see also Ashley 2007). Farms located in areas with strong tidal currents will expose salmon to repeatedly changing current conditions. At more extreme current velocities than Johansson et al. (2014) observed, it is unclear how the group structure and behaviour of the fish change. As the fish approach their maximum sustainable swimming capacity, all available energy would assumedly be allocated to swimming. This may result in decreased energy stores and thus reduced growth (East \& Magnan 1987, Farrell et al. 1991, Jørgensen \& Jobling 1993) and welfare (e.g. Ashley 2007).

In previous studies, no negative effects of fast water current velocities were found on behaviour and fin erosion, and positive effects of swimming speeds up to $2.5 \mathrm{BL} \mathrm{s}^{-1}$ have been reported (East \& Magnan 1987). However, negative effects of fast current velocity on physiology and production performance have been demonstrated in Solstorm et al.
(2015) and thus are hypothesised to also have impacts at the behavioural level. This study performed a detailed analysis of behaviour and fin erosion when Atlantic salmon post-smolts were exposed to water currents of slower and faster velocities than their preferred range, with the latter prevailing in farms located at exposed sites.

\section{MATERIALS AND METHODS}

\section{Facilities and experimental animals}

A behavioural study of post-smolt Atlantic salmon (AquaGen strain, hatched March 2011) exposed to water currents was conducted at the Tank Environmental Laboratory at the Institute of Marine Research, Matre (Norway), during 6 wk starting April 2012. The study was part of a larger experiment also investigating physiological effects, where a more detailed description of setup and experimental design can be found (Solstorm et al. 2015). Fish (98.6 $\pm 20 \mathrm{~g}$, $22.3 \pm 1.3 \mathrm{~cm}$, mean $\pm \mathrm{SD}$ ) were transferred to raceways at a mean $( \pm \mathrm{SE})$ stocking density of $38.7 \pm$ $0.28 \mathrm{~kg} \mathrm{~m}^{-3}(\mathrm{n}=80$ per raceway) as smolts. This density was chosen as representative for typically observed swimming densities in sea cages, where salmon are known to trade off variable environmental drivers, including temperature and water currents (Oppedal et al. 2011a,b, Johansson et al. 2014). Prior to smoltification, fish had been reared in tanks $(\varnothing 5 \mathrm{~m})$ under natural light and temperature conditions. To finalise smoltification, fish were kept on a constant light regime for $8 \mathrm{wk}$ at $8^{\circ} \mathrm{C}$ with a flow of $150 \mathrm{l} \mathrm{min}^{-1}$ until all fish had smoltified.

Raceways (trans-sectional area $0.10 \mathrm{~m}^{2}, \varnothing 0.36 \mathrm{~m}$, length $2.0 \mathrm{~m}$, giving a volume of $0.20 \mathrm{~m}^{3}$ ) were submerged in circular tanks $\left(\varnothing 3 \mathrm{~m}, 5.3 \mathrm{~m}^{3}\right)$. A laminar water current velocity was produced by an electric engine (Minn Kota RT80/EM, Johnson Outdoors Marine Electronics) with adjustable speed followed by a honeycomb (5.0 mm opening, $101.6 \mathrm{~mm}$ thickness, PC $5.0 \mathrm{G} 4$, Plascore). Water temperature was $10^{\circ} \mathrm{C}$, water exchange was $120 \mathrm{lmin}^{-1}$, salinity was $33 \mathrm{psu}$ and dissolved oxygen levels were above $80 \%$. A constant light regime was maintained during the experiment, and the fish were fed (Skretting Spirit 75) in excess every $15 \mathrm{~min}$ throughout the day $(24 \mathrm{~h})$ to ensure that food would not be a limiting factor. Feed was distributed by automatic feeding units (Arvo-Tec T Drum 2000, http:// www.arvotec.fi) controlled from custommade computer software (SD Matre, Normatic AS). An underwater video camera (SV27, SeaVision) was 
mounted in the middle of each raceway, with the field of view covering the posterior area of the chamber. Video recordings were stored on a central PC by a video capture card (GV-800, GeoVision) and multicamera surveillance system (CV-800, GeoVison).

\section{Experimental design}

Fish were kept at a velocity of $0.5 \mathrm{BL} \mathrm{s}^{-1}$ in the raceways to acclimatise for $19 \mathrm{~d}$ prior to the experiment. This velocity was chosen as it is the velocity typically used for acclimation prior to swimming performance tests in salmonids, and all fish were to experience a change when the trial commenced. During the experiment, fish were kept at 3 different water current velocities for $6 \mathrm{wk}$ in 4 replicate raceways: slow, moderate and fast velocities corresponding to $0.2 \pm 0.02$, $0.8 \pm 0.01$ and $1.5 \pm 0.02 \mathrm{BL} \mathrm{s}^{-1}$ (mean $\pm \mathrm{SE}$ ), respectively. In this setup, water current velocity was considered the same as swimming speed since the fish had to hold station against the current not to be swept back into the netting and had limited space (9 to $7 \mathrm{BL}$, upstream-downstream direction) to move around freely. Slow current velocity was adjusted to be close to zero without compromising oxygen levels and the transport of faeces and food waste out of the raceway. Moderate current velocity was selected to be in the range of the preferred swimming speed (Tudorache et al. 2011). Fast current velocity was chosen to be twice the amplitude of the moderate but still below the critical swimming speed (Tang \& Wardle 1992, Stevens et al. 1998), although actual velocity was slightly lower. After $3 \mathrm{wk}$, the currents were adjusted to the increased fish length (due to growth) to maintain the same velocity in body length per second.

The experiment was conducted in accordance with laws and regulations of the Norwegian Regulation on Animal Experimentation (application ID 4146).

\section{Behavioural observations}

Video recordings of fish behaviour were made without disturbance in Weeks 0, 2, 4 and 6 by the GeoVision system preprogrammed to record for $12 \mathrm{~min}$ and $30 \mathrm{~s}$ during 08:00 to $12: 00 \mathrm{~h}$ simultaneously in 2 tanks at a time to increase the video quality. Recordings in Week 0 were done $1 \mathrm{~d}$ after the current velocities were set; the other recordings were done at the beginning of the week. Fish behaviour was classified as interactions or movements affecting the group structure (structural movements) and ranked according to the assumed intention (Table 1). Ranking was classified from 1 to 6 , with 1 as the highest ranking. Biting was given the highest ranking based on an assumed impact scale. When one type of behaviour was documented, other behaviours were assumed a consequence of the first behaviour, and thus lowerranked behaviours were not documented. For instance, a biting attempt could be preceded by bursts and collisions, but since these behaviours were of lower ranking, only the biting was documented. Structural behaviours were analyzed according to a Cartesian coordinate system, where $\mathrm{X}$ and $\mathrm{Y}$ are movements in the cross-sectional plane, and $-\mathrm{Z}$ movements are movements with the flow. Behaviours were analysed for $12 \mathrm{~min}$ and $30 \mathrm{~s}$, and the number of behavioural occurrences per minute was calculated.

\section{Fin erosion}

External injuries and fin erosion were recorded on all fish before and after the experiment. Fin erosion was observed on the pectoral, dorsal, pelvic, anal and caudal fins and divided into 3 categories: fins with 0 to $10 \%$ of the fin missing (eroded) were classified as uninjured due to difficulties in assessing a perfect fin ( $0 \%$ erosion), fins with 10 to $50 \%$ erosion were classified as moderate fin erosion and fins with $>50 \%$ erosion were classified as severe fin erosion. This

Table 1. Definitions of the behavioural categories used. Behaviours were ranked from 1 to 6 , with 1 as the highest ranking

\begin{tabular}{|c|c|c|}
\hline Behaviour & Definition & Ranking \\
\hline \multicolumn{3}{|l|}{ Interaction } \\
\hline Biting & Active attempt to bite another fish & 1 \\
\hline Displacement & $\begin{array}{l}\text { A fish forces another out of position, } \\
\text { with or without close contact }\end{array}$ & 2 \\
\hline Intentional collision & $\begin{array}{l}\text { A fish directs its swimming and bumps } \\
\text { into another fish intentionally, not } \\
\text { resulting in a bite attack or displace- } \\
\text { ment of the attacked fish }\end{array}$ & 3 \\
\hline \multicolumn{3}{|c|}{ Structural movement } \\
\hline Burst & Fast acceleration against the current & 4 \\
\hline Move -Z & $\begin{array}{l}\text { Turning and swimming with the current } \\
\text { instead of against the current }\end{array}$ & 5 \\
\hline Move XY & $\begin{array}{l}\text { Vertical movements in X or Y direction, } \\
\text { with a relocation of at least } 0.5 \text { body } \\
\text { length not followed by other higher- } \\
\text { ranked behaviour }\end{array}$ & 6 \\
\hline
\end{tabular}


classification was based on an index used by Swedish governmental agencies and chosen as the index based on the observers' experience. The index is a modified version based on Person-Le Ruyet et al. (2007), where the 0 group has been judged irrelevant for farmed fish and is thus removed from the index. Difficulties distinguishing between their levels 2 and 3 were simplified by adding them to the same group (here, moderate fin erosion). Fin erosions were also classified as either new damage with bleeding or older damage that may have healed.

\section{Statistics}

Data analyses were performed using $\mathrm{R}$ software Version 3.1.0 (Copyright 2009, The R Foundation for Statistical Computing, Vienna). Counts are reported as mean number of counts $\mathrm{min}^{-1} \pm$ SE. Deviance in behaviour counts was modelled using generalized linear models with quasi-Poisson errors, as recommended for count data with over-dispersion (Crawley 2012). Week numbers $(0,2,4$ and 6$)$ and treatments were set as explanatory factors in the models (function glm, R). Model simplification was performed in cases where the simpler model was not significantly different from the more complex model (function ANOVA, R, test = $\mathrm{Chi}_{i}$ Crawley 2012). Fin erosion data were analyzed in a similar way; however, as data were proportional (percentage fish with damage), the error distribution was set as binomial and, in the case of overdispersion, quasi-binomial (Crawley 2012). Ftests were used to compare the original to simplified models (function ANOVA, $\mathrm{R}$, test $=F_{\text {; }}$ Crawley 2012). Significance level was set at $p<$ 0.05 .

During the experiment, 2 replicates were eliminated due to technical problems-one from the fast current velocity in Week 5 and one from the moderate current velocity in Week 4resulting in triplicate treatments for the aforementioned groups at the final sampling.

\section{RESULTS}

\section{Behavioural observations}

\section{Group structure}

Current velocity had a large influence on structural movements, with the highest frequency of behaviours observed in fish kept at the slower velocity and decreasing levels of movement with the moderate and faster velocities (Fig. 1). When the treatment velocities were applied, behaviours immediately changed. Similar differences were observed in the following $4 \mathrm{wk}$. In the final week, there was an increase of structural movements at moderate velocity compared to the second week, due to increased horizontal movements (Move XY). Even so, fish at both moderate and faster velocities had fewer movements than fish at slower velocity. Fish at faster velocity also showed significantly fewer movements than fish at moderate velocity in the final week. Except for an increase in horizontal movements from Week 2 until Week 6, at moderate velocity, there were no changes over time within treatments in the different types of structural behaviours (Fig. 1).

\section{Interactions}

More interactions were observed in fish kept at slow velocity compared to both moderate and faster velocities (Fig. 2). Fish at fast velocity did not differ significantly compared to moderate velocity, but a decreasing trend of interactions was observed. At slow velocity, fewer collisions were observed in Week 4 compared to Weeks 0 and 2, resulting in no treatment effect in Week 4 . In the other interacting behaviours, no effects were observed over time.

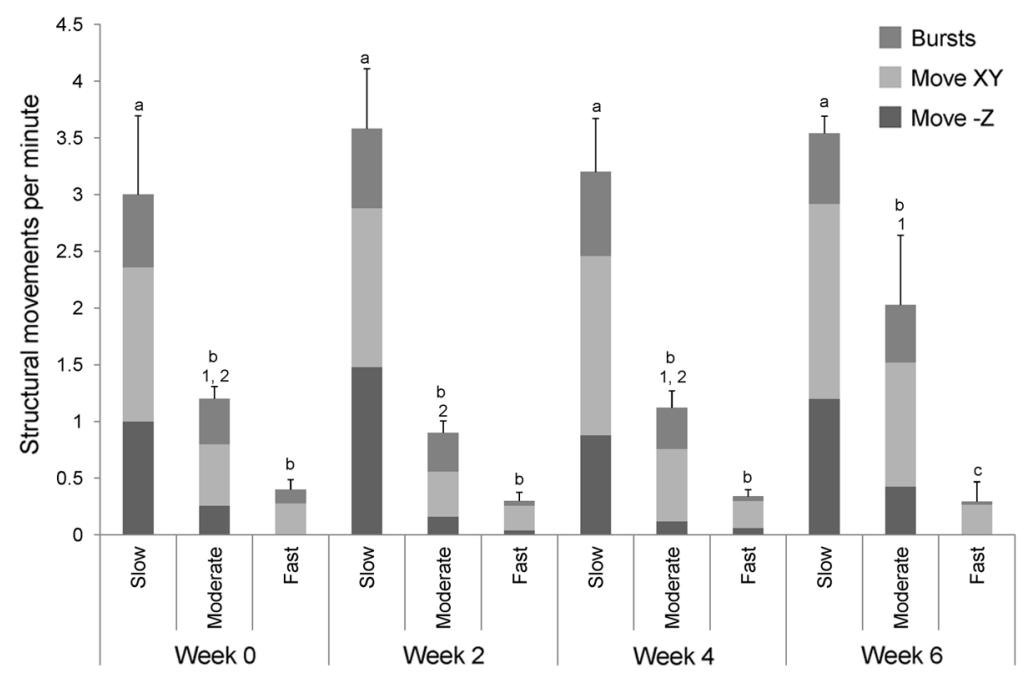

Fig. 1. Mean of structural behaviours per minute in fish at 3 different water current velocities (slow, 0.2 body length [BL] s${ }^{-1}$; moderate, $0.8 \mathrm{BL} \mathrm{s}^{-1}$; and fast, $1.5 \mathrm{BL} \mathrm{s}^{-1}$ ) over $6 \mathrm{wk}$. Error bars represent SE of total occurrences. Lowercase letters denote significant differences between current velocities, and numbers denote significant differences between weeks based on the cumulated behaviours $(p<0.05)$ 


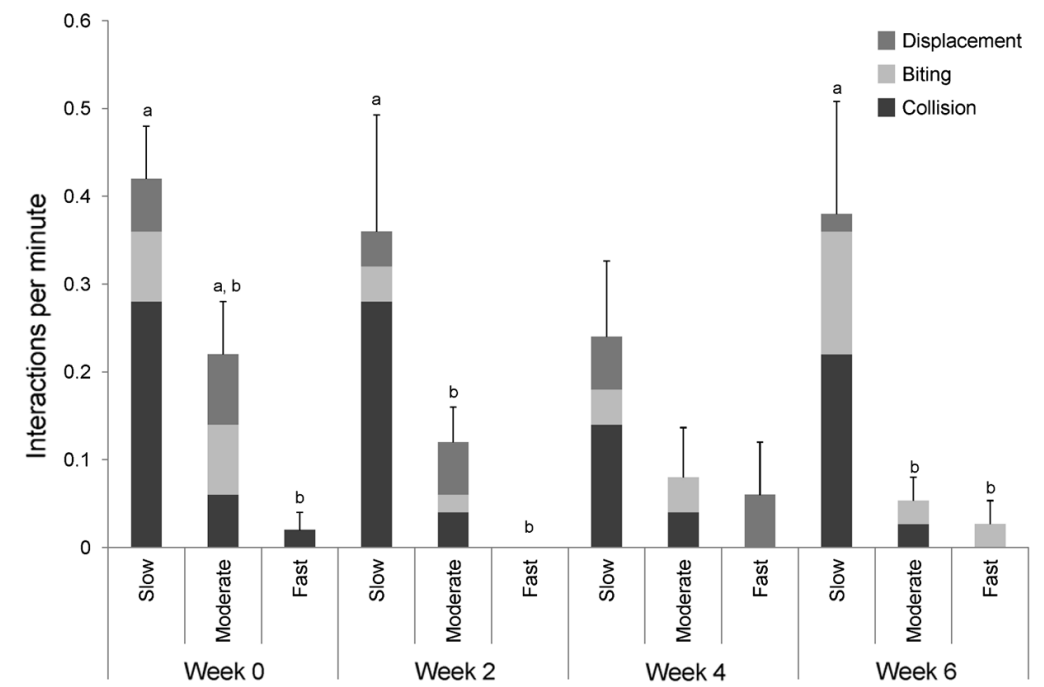

Fig. 2. Mean of interacting behaviours per minute in fish at 3 different water current velocities (slow, 0.2 body length [BL] s${ }^{-1}$; moderate, $0.8 \mathrm{BL} \mathrm{s}^{-1}$; and fast, 1.5 BL s${ }^{-1}$ ) over $6 \mathrm{wk}$. Error bars represent SE of total occurrences. Lowercase letters denote significant difference between current velocities based on cumulated interactions $(\mathrm{p}<0.05)$

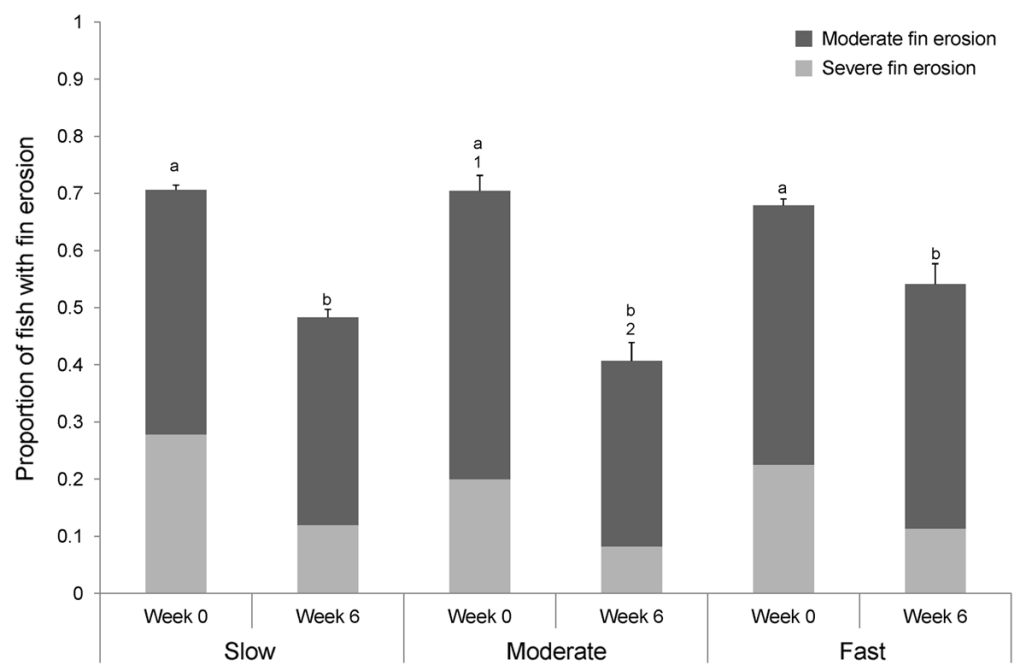

Fig. 3. Mean of cumulated fin erosions at start and end of experiment in fish kept at slow $\left(0.2\right.$ body length [BL] s $\left.{ }^{-1}\right)$, moderate $\left(0.8 \mathrm{BL} \mathrm{s}^{-1}\right)$ and fast $(1.5 \mathrm{BL}$ $\mathrm{s}^{-1}$ ) water current velocities. The columns are separated into fish with moderate fin erosion and fish with severe fin erosion. Error bars show SE of cumulated fin erosions. Lowercase letters denote significant differences between current velocities, and numbers denote significant differences between weeks $(\mathrm{p}<0.05)$

\section{Fin erosion and other injuries}

The proportion of fish with fin erosion decreased from Weeks 0 to 6 in all groups (Fig. 3). Severe fin erosion decreased in fish at all 3 velocities over time, while moderate fin erosion only decreased at the moderate velocity. However, at the faster velocity, there was an increase in new fin erosion from the start to the end of the experiment (Fig. 4). New fin erosion was also more prevalent in fish at faster velocity than at moderate and slower velocities.

The increase in new fin erosion was caused by an increase in caudal fin erosion (Fig. 5). Damage on the dorsal fin was significantly less frequent at the end, with no effect of velocity. Fish at faster velocity had a significantly higher frequency of caudal fin erosion than fish at slower velocity at the end of the experiment. No effects could be seen for the other fin erosions.

\section{DISCUSSION}

The water current velocities had an effect on both behaviour and fin erosion in post-smolt salmon in raceways. Increasing current velocities induced a higher level of organised swimming in salmon, while agonistic behaviour decreased. However, the prevalence of new fin erosion increased at the fast current velocity. These findings suggest that increased current is positive but that welfare may be compromised above a certain velocity.

When the fish are not forced to swim against a current, they may choose various behavioural strategies within the tank. Some fish move at random, while others are stationary. Some may display territorial behaviour, while others are subordinate (Fernö \& Holm 1986, Adams et al. 1995). The higher frequency of movements affecting group structure (structural movements) and agonistic behaviour in fish kept at slow current velocity has also been observed in previous studies on salmonids, although these studies did not observe the group structure in detail (East \& Magnan 1987, Christiansen \& Jobling 1990, Christiansen et al. 1992, Jørgensen \& Jobling 1993, Adams et al. 1995). It is assumed that aggression is energetically costly and will result in decreased growth (East \& Magnan 1987, Christiansen \& Jobling 1990). Solstorm et al. (2015) found, based on physiological parameters, that some individuals at slow velocity experienced elevated 


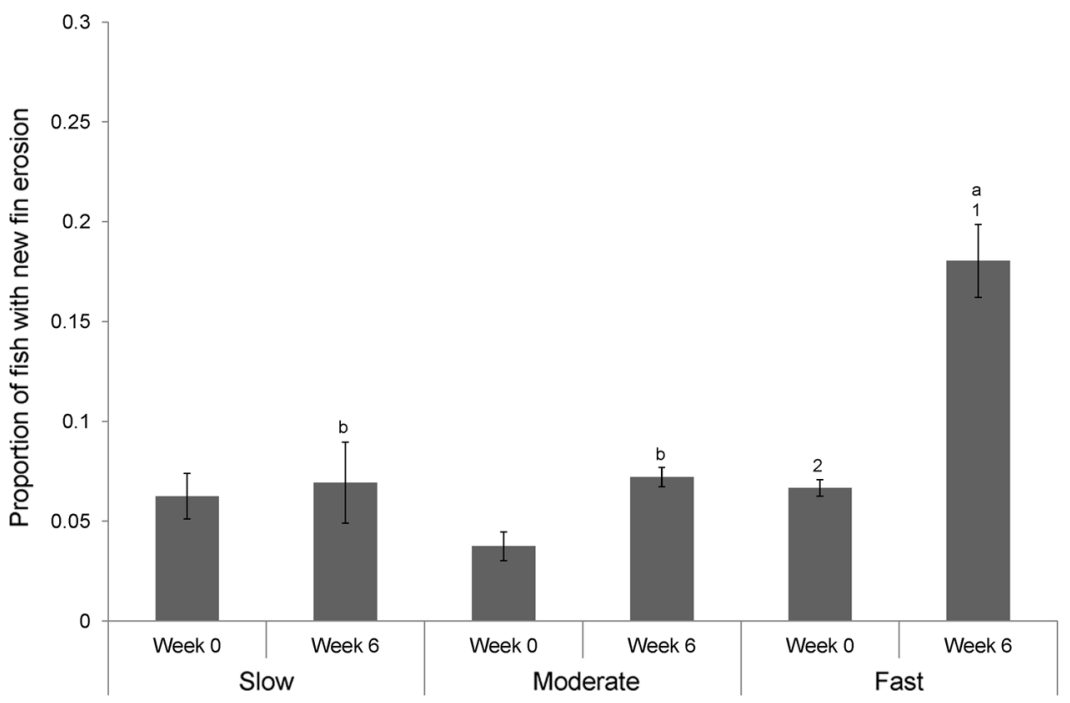

Fig. 4. Mean proportion of fish with new fin erosion at start and end of experiment in fish kept at slow $\left(0.2\right.$ body length [BL] s$\left.{ }^{-1}\right)$, moderate $\left(0.8 \mathrm{BL} \mathrm{s}^{-1}\right)$ and fast $\left(1.5 \mathrm{BL} \mathrm{s}^{-1}\right)$ water current velocities. Error bars represent SE. Lowercase letters denote significant differences between current velocities, and numbers denote significant differences between weeks $(\mathrm{p}<0.05)$

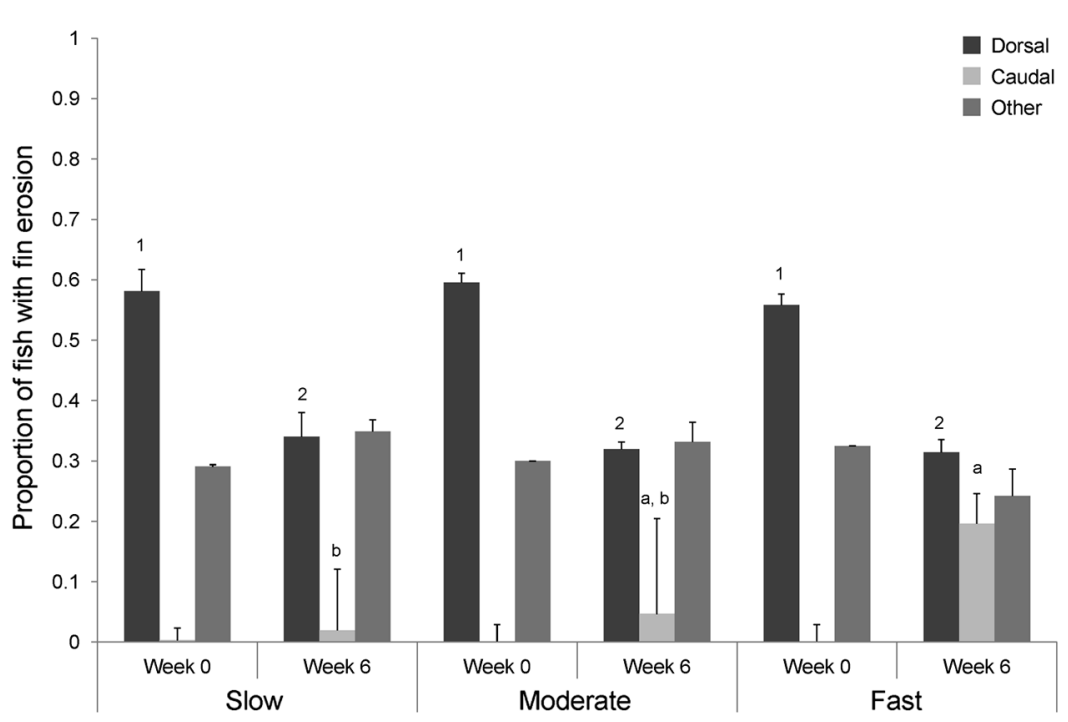

Fig. 5. Mean proportion of fin erosions separated into dorsal, caudal or other, with other including pectoral, pelvic and anal fins. Columns are presented for fish kept at slow $\left(0.2\right.$ body length $\left.[\mathrm{BL}] \mathrm{s}^{-1}\right)$, moderate $\left(0.8 \mathrm{BL} \mathrm{s}^{-1}\right)$ and fast (1.5 BL s ${ }^{-1}$ ) water current velocities at the start and end of a 6 wk experiment. Error bars represent SE. Lowercase letters denote significant differences between water current velocities, and numbers denote significant differences between weeks $(p<0.05)$

stress levels. This may suggest that agonistic behaviour and structural movements displayed at slow velocity are stressful for the individual, resulting in compromised welfare for the individual. However, fish at slow velocity had the same growth as fish at moderate velocity (Solstorm et al. 2015), indicating that the level of interactions at slow velocity was not severe enough to result in decreased growth. Also, when relating the level of agonistic behaviour to previous studies, these values are low (East \& Magnan 1987, Adams et al. 1995). Adams et al. (1995) observed approximately the same number of agonistic behaviours in exercised Arctic charr as was seen at slow velocity in this study, but in their setup, 10 fish were observed, whereas in this study, up to 80 fish were studied. In our setup, there is a possible risk that the slow velocity induced structural movements and interactions as an effect of the possibility to swim at voluntary speed and thereby create an organised group structure. In contrast to raceways, salmon in cages are largely free to choose their swimming speed and create an organized structure, making results from our slow velocity difficult to relate to commercial situations, where fish are commonly held in sea cages. Farmed salmon are raised in high densities and are thus habituated to social organisation; rapid changes in current velocity can break down their schooling structure, and this could cause brief disorder. Johansson et al. (2014) observed that after this type of disorder, salmon strive to organise a new structure.

Fin erosion is a welfare problem that can arise from increased agonistic behaviour. Damage to the tissue is a direct violation of one of the Five Freedoms, i.e. freedom from pain and injury (defined by FAWC [1995]) and may also lead to health problems, with increased susceptibility to pathogens due to damaged tissue (Turnbull et al. 1996). Even though a fish's ability to experience pain is widely debated, the fins contain nociceptors, and adverse behaviour after fin clipping has been demonstrated, suggesting that fin erosion contributes to negative welfare (Roques et al. 2010, Noble et al. 2012). Causes for fin erosion are nipping from others, abrasion and bacterial infection (Latremouille 2003). Fin nipping mostly targets the dorsal fin in salmonid parr (Turnbull et al. 1998). The high frequency of dorsal fin erosions at the start of our experiment 
could be explained by the fish coming directly from the freshwater life stage potentially combined with periodic restrictions in feed availability, as often seen under commercial parr production. At the parr stage in fresh water, wild salmon are territorial and frequently show agonistic behaviours (Keenleyside \& Yamamoto 1962), while fish stressed by feed restrictions in aquaculture production units may show increased fin nipping and thus erosion (Noble et al. 2008). The reduction of cumulated fin erosions over time in our experiment may therefore be explained by a life stage-related decrease in agonistic behaviour, where salmon go from being territorial on riverbeds to becoming non-territorial pelagic swimmers in the open ocean (e.g. McCormick et al. 1998). Lending evidence to this is the fact that we observed the highest rate of agonistic behaviours at slower velocity, yet fin erosion declined over time. This suggests that the conditions before the experiment promoted fin erosion.

Previously documented behavioural effects with respect to reduced aggression, increased group structure and decreased fin erosion (East \& Magnan 1987, Christiansen \& Jobling 1990, Christiansen et al. 1992, Jørgensen \& Jobling 1993, Adams et al. 1995) are in line with the results of the present study. Moderate current velocity forced the fish to swim against the current to prevent being swept back into the netting or colliding with other fish, which reduced interactions and structural movements. However, even though agonistic behaviours decreased at moderate compared to slow velocity, the fish displayed the same low level of fin erosion at the end of the experiment.

In previous studies, current velocities far exceeding our fastest velocity caused reduced aggression and improved fin quality in juvenile Arctic charr, brook charr and Atlantic salmon (East \& Magnan 1987, Christiansen \& Jobling 1990, Jørgensen \& Jobling 1993, Adams et al. 1995). At our fast velocity (1.5 BL $\mathrm{s}^{-1}$ ), fish focused on swimming against the current to avoid being swept back into the netting; thus, structural movements and agonistic behaviour were almost absent. Yet, caudal fin erosion increased at the end of the experiment in the fast velocity. During daily maintenance, fish were observed to have difficulties in maintaining their position without unintentionally colliding with each other and the back netting. Hence, abrasion is the most likely cause for the observed caudal fin erosion, and this is supported by the increase in new fin erosion over time at the fast current velocity. Our experimental setup differed from previous studies and could explain the different outcome that we observed. As described in Solstorm et al. 2015, it is difficult to compare swimming speed to earlier studies where homogeneity of the current and absolute swimming speed is difficult to evaluate. Previous studies have mostly been conducted in open circular tanks (East \& Magnan 1987, Christiansen \& Jobling 1990, Jørgensen \& Jobling 1993, Adams et al. 1995) with no back netting where the fish can attain abrasive fin erosion, and therefore our experimental setup may have unintentionally caused further fin erosion. Yet, if this is the case, our setup is relevant for fish in sea cages, where fast current velocities could force the fish into the cage netting and thereby cause the same abrasion. With the trend of having land-based post-smolt production, these aspects should not constitute a problem. Abrasion to other fins could also arise from the use of raceways (Arndt et al. 2001), but in our setup, the rough fin index could not detect any clear differences. It is possible that the rounded bottom in our raceways had a positive effect, since no fish were observed to stand on the bottom.

Previous studies have assumed that reduced interactions between fish are always positive and have not focused on the potential need for fish to express different types of behaviour. It could be that fast current velocity does not permit the fish to move around and interact in the environment, which could be seen as a violation of one of the Five Freedoms (defined by FAWC [1995]), i.e. the possibility to perform normal behaviour. In salmon feeding areas in the wild, such as the Nordic seas, individuals experience mean water velocities of 20 to $35 \mathrm{~cm} \mathrm{~s}^{-1}$, with considerably higher maximum velocities exceeding $100 \mathrm{~cm} \mathrm{~s}^{-1}$ (Orvik et al. 2001). From an evolutionary perspective, salmon should therefore be adapted to a range of velocities, and normal behaviour therefore needs to have a wide range. Even so, wild salmon may drift along when velocities exceed limits in swimming performance, while farmed salmon are forced to maintain position within the cage. This may lead to welfare acceptable limits being breached in aquaculture settings. At the slower velocity, frequent movements and interactions could create a stressful environment for some individuals (Solstorm et al. 2015). Yet, this does not apply to wild salmon, as they do not typically swim in schools in the open sea, and even if interactions occur, they may quickly escape each other in an infinite water volume. As mentioned above, farmed salmon in cages with slow water velocities choose their own swimming speed, making results from slow velocity difficult to relate to fish held in sea cages and therefore welfare evaluation 
from this group is not commercially relevant. Fish at moderate velocity display a lower degree of interactions and movements, but the current does not seem to be restrictive. The moderate velocity in our study is also within the range considered as the preferable swimming speed for brook charr (Tudorache et al. 2011), as well as in the range of swimming speeds for salmonids in the wild (Drenner et al. 2012). Swimming speeds that are preferred or chosen should be expected to optimise welfare. In view of the welfare concept based on allostasis (Korte et al. 2007), the fish at moderate velocity seemed to uphold stability through change the best (see also Solstorm et al. 2015), resulting in the highest welfare. Altogether, from a welfare perspective, our study showed that a moderate water current velocity likely contributed to the highest welfare with regard to social interactions, swimming speed and fin erosion.

\section{CONCLUSIONS}

Our results indicate that there is an upper limit in current velocity where positive effects are gained. An increase in water current velocity and the resulting swimming speed is initially positive by reducing structural movements and agonistic behaviour, but if the current is too strong, it can result in negative effects like increases in new fin damage and a reduced possibility to express different behaviours.

The fish in the present study displayed a behavioural plasticity when rapidly adapting their behaviour to different water current velocities at the start of the experiment, analogous to the response to changing currents in the field (Johansson et al. 2014). This suggests that currents are an effective way of controlling behaviours that may compromise fish welfare. If the fish experience water currents that are too fast, the netting could be modified to decrease the currents (Klebert et al. 2013), or more sheltered areas may be selected. Further studies on both fish behaviour and physiology under different water current velocities are needed to identify optimal current velocities for salmon net cages.

Acknowledgements. We thank the staff at IMR Matre for their assistance during the experiments. The work was funded by the Research Council of Norway Grant No. 207116/S40, Exposed Farming. All experimental work was conducted in accordance with the laws and regulations for experiments and procedures on live animals in Norway, following the Norwegian Regulation on Animal Experimentation 1996. The experiment was approved by Forsøksdyrutvalget (FOTS ID 4146).

\section{LITERATURE CITED}

Adams CE, Huntingford FA, Krpal J, Jobling M, Burnett SJ (1995) Exercise, agonistic behavior and food acquisition in Arctic charr, Salvelinus alpinus. Environ Biol Fishes 43:213-218

Arndt RE, Routledge MD, Wagner EJ, Mellenthin RF (2001) Influence of raceway substrate and design on fin erosion and hatchery performance of rainbow trout. $\mathrm{N}$ Am J Aquacult 63:312-320

Ashley PJ (2007) Fish welfare: current issues in aquaculture. Appl Anim Behav Sci 104:199-235

Blyth PJ, Purser GJ, Russel JF (1993) Detection of feeding rhythms in seacaged Atlantic salmon using a new feeder technology. In: Reinertsen $\mathrm{H}$, Dahle LA, Jørgensen L, Tvinnereim K (eds) Fish farming technology. Balkema, Rotterdam, p 209-216

Christiansen JS, Jobling M (1990) The behavior and the relationship between food intake and growth of juvenile Arctic charr, Salvelinus alpinus L., subjected to sustained exercise. Can J Zool 68:2185-2191

> Christiansen JS, Svendsen YS, Jobling M (1992) The combined effects of stocking density and sustained exercise on the behaviour, food intake, and growth of juvenile Arctic charr (Salvelinus alpinus L.). Can J Zool 70: $115-122$

Crawley MJ (2012) The R book. John Wiley \& Sons, Chichester

Drenner SM, Clark TD, Whitney CK, Martins EG, Cooke SJ, Hinch SG (2012) A synthesis of tagging studies examining the behaviour and survival of anadromous salmonids in marine environments. PLoS ONE 7:e31311

East P, Magnan P (1987) The effect of locomotor activity on the growth of brook charr, Salvelinus fontinalis Mitchill. Can J Zool 65:843-846

Farrell AP, Johansen JA, Suarez RK (1991) Effects of exercise training on cardiac performance and muscle enzymes in rainbow trout, Oncorhynchus mykiss. Fish Physiol Biochem 9:303-312

Fernö A, Holm M (1986) Aggression and growth of Atlantic salmon parr. I. Different stocking densities and size groups. Fiskeridir Skr Ser Havunders 18:113-122

> Johansson D, Laursen F, Fernö A, Fosseidengen JE and others (2014) The interaction between water currents and salmon swimming behaviour in sea cages. PLoS ONE 9:e97635

Jørgensen EH, Jobling M (1993) The effects of exercise on growth, food utilization and osmoregulatory capacity of juvenile Atlantic salmon, Salmo salar. Aquaculture 116: 233-246

Juell JE, Westerberg H (1993) An ultrasonic telemetric system for automatic positioning of individual fish used to track Atlantic salmon (Salmo salar L.) in a sea cage. Aquacult Eng 12:1-18

> Kadri S, Metcalfe NB, Huntingford FA, Thorpe JE (1991) Daily feeding rhythms in Atlantic salmon in sea cages. Aquaculture 92:219-224

Keenleyside MHA, Yamamoto FT (1962) Territorial behaviour of juvenile Atlantic salmon (Salmo salar L.). Behaviour 19:139-168

> Klebert P, Lader P, Gansel L, Oppedal F (2013) Hydrodynamic interactions on net panel and aquaculture fish cages: a review. Ocean Eng 58:260-274

Korte SM, Olivier B, Koolhaas JM (2007) A new animal welfare concept based on allostasis. Physiol Behav 92: 
$422-428$

Latremouille DN (2003) Fin erosion in aquaculture and natural environments. Rev Fish Sci 11:315-335

McCormick SD, Hansen LP, Quinn TP, Saunders RL (1998) Movement, migration, and smolting of Atlantic salmon (Salmo salar). Can J Fish Aquat Sci 55:77-92

Noble C, Kadri S, Mitchell DF, Huntingford FA (2008) Growth, production and fin damage in cage-held $0+$ Atlantic salmon pre-smolts (Salmo salar L.) fed either a) on-demand, or b) to a fixed satiation-restriction regime: data from a commercial farm. Aquaculture 275:163-168

Noble C, Jones HAC, Damsgård B, Flood MJ and others (2012) Injuries and deformities in fish: their potential impacts upon aquacultural production and welfare. Fish Physiol Biochem 38:61-83

Oppedal F, Dempster T, Stien LH (2011a) Environmental drivers of Atlantic salmon behaviour in sea-cages. Rev Aquacult 311:1-18

Oppedal F, Vågseth T, Dempster T, Juell JE, Johansson D (2011b) Fluctuating sea-cage environments modify the effects of stocking densities on production and welfare parameters of Atlantic salmon (Salmo salar L.). Aquaculture 315:361-368

Orvik KA, Skagseth Ø, Mork M (2001) Atlantic inflow to the Nordic seas: current structures and volume fluxes from moored current meters, VM-ADCP and SeaSoar-CTD observations, 1995-1999. Deep-Sea Res I 48:937-957

Person-Le Ruyet J, Le Bayon N, Gros S (2007) How to assess fin damage in rainbow trout, Oncorhynchus mykiss? Aquat Living Resour 20:191-195

Roques JAC, Abbink W, Geurds F, van de Vis H, Flik G (2010) Tailfin clipping, a painful procedure: studies on Nile tilapia and common carp. Physiol Behav 101:533-540

Schneider R, Nicholson BL (1980) Bacteria associated with fin rot disease in hatchery-reared Atlantic salmon (Salmo salar). Can J Fish Aquat Sci 37:1505-1513

Editorial responsibility: Marianne Holmer, Odense, Denmark
Solstorm F, Solstorm D, Oppedal F, Fernö A, Fraser TWK, Olsen RE (2015) Fast water currents reduce production performance of post-smolt Atlantic salmon Salmo salar. Aquacult Environ Interact 7:125-134

Stevens ED, Sutterlin A, Cook T (1998) Respiratory metabolism and swimming performance in growth hormone transgenic Atlantic salmon. Can J Fish Aquat Sci 55: 2028-2035

Stien LH, Bracke MBM, Folkedal O, Nilsson J and others (2013) Salmon Welfare Index Model (SWIM 1.0): a semantic model for overall welfare assessment of caged Atlantic salmon: review of the selected welfare indicators and model presentation. Rev Aquacult 5:33-57

Sutterlin AM, Jokola KJ, Holte B (1979) Swimming behaviour of salmonid fish in ocean pens. J Fish Res Board Can 36:948-954

Tang J, Wardle CS (1992) Power output of two sizes of Atlantic salmon (Salmo salar) at their maximum sustained swimming speeds. J Exp Biol 166:33-46

Tudorache C, O'Keefe RA, Benfey TJ (2011) Optimal swimming speeds reflect preferred swimming speeds of brook charr (Salvelinus fontinalis Mitchill, 1874). Fish Physiol Biochem 37:307-315

Turnbull JF, Richards RH, Robertson DA (1996) Gross, histological and scanning electron microscopic appearance of dorsal fin rot in farmed Atlantic salmon, Salmo salar L., parr. J Fish Dis 19:415-427

Turnbull JF, Adams CE, Richards RH, Robertson DA (1998) Attack site and resultant damage during aggressive encounters in Atlantic salmon (Salmo salar L.) parr. Aquaculture 159:345-353

Farm Animal Welfare Council (FAWC) (1995) Five Freedoms of the Farm Animal Welfare Council. http:// webarchive.nationalarchives.gov.uk/20121007104210/ http:/www.fawc.org.uk/freedoms.htm (accessed on 20 September 2015)

Submitted: October 1, 2015; Accepted: March 21, 2016 Proofs received from author(s): May 3, 2016 